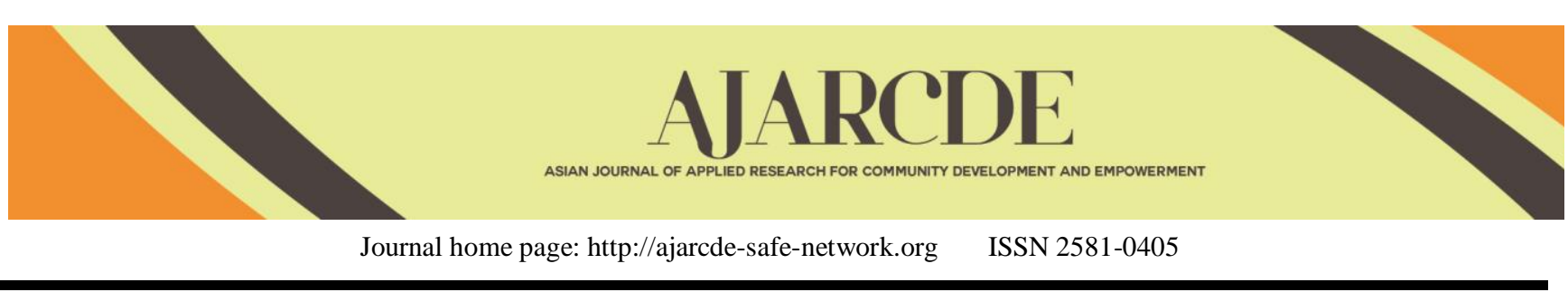

\title{
Effects of Co-substrate Concentrations on the Anaerobic Co-Digestion of Common Reed and Cow Dung
}

\author{
Giang Van Tran ${ }^{1}$, Yuwalee Unpaprom ${ }^{2}$ and Rameshprabu Ramaraj ${ }^{1 *}$ \\ ${ }^{1}$ School of Renewable Energy, Maejo University, Chiang Mai 50290, Thailand. \\ ${ }^{2}$ Program in Biotechnology, Faculty of Science, Maejo University, Chiang Mai 50290, Thailand. \\ *Corresponding author, email: rameshprabu@mju.ac.th ; rrameshprabu@gmail.com
}

\section{ARTICLE INFO}

Article History:

Received: July 29, 2019

Final Revision: November 24, 2019

Available Online: December 21, 2019

\section{KEYWORDS}

Determinants of SMEs, Renewable Energy

Market, ASEAN Market

\section{CORRESPONDING AUTHOR}

*E-mail: rameshprabu@mju.ac.th ;

\section{A B S T R A C T}

\begin{abstract}
The biochemical methane potentials for common reed (Phragmites australis) and cow dung from northern Thailand, Chiang Mai city were investigated. This study aims to evaluate optimal parameters for the substrate of common reed and cow dung with different ratios (i.e. 1:1, 2:1 and 1:2) for improving the quality of methane content and biogas production. The effect of the co-substrate mixture was carried out in a batch reactor operated under room temperature and hydraulic retention time (HRT) of 45 days. The experiments were conducted in the fermenter with a working volume of $2.5 \mathrm{~L}$ and a total volume of $3 \mathrm{~L}$. The substrate was containing $15 \%$ of total solids (TS) and fermentation at initial $\mathrm{pH} 7$. Biodegradation of substrate stated that chemical oxidation demand (COD) removal was $52.38 \%$, the utilization of volatile solid was $75.46 \%$. The results were achieved at ratio 2:1 (common reed and cow dung) reached the highest methane content and total biogas yield are $70 \%$ and $20,015 \mathrm{ml}$, respectively. Consequently, the results of this study suggested that mixing ratios of influence on the fermentation process and monitoring parameters were significant for further scale up or large-scale design of enriched methane content and biogas production..
\end{abstract}

\section{INTRODUCTION}

\subsection{Research Background}

The resources of raw materials for the production of clean fuels up to now has been almost entirely utilized [1,2], so finding new material sources to replace fossil fuels, which directly affects the environment is more necessary than ever. Presently, a prominent way for discovering of researchers is frequently keeping an eye on the wild or rural areas where new materials are extraordinary and abundant. Especially, feedstock which derived from wetland biomass, one of the rich and diverse materials [3]. Moreover, it is always available in nature with intense vitality and can be replenished in the course of nature survival. In particular, grass has still been considered as one of the materials with great potential not only for providing clean and plentiful energy sources. Also, it brought many benefits on minimizing environmental damage and bearing economic value [4,5], thus promoting the development of clean energy sector to reduce the harmful effects of the atmosphere's influential of energy sources.

\subsection{Literature Review}

Biogas is generated via anaerobic digestion (AD) which undergoes four primarily phases: hydrolysis, acidogenesis, acetogenesis, and methanogenesis [6]. It is considered to have long-term potential because of the feasibility [2,7]. On the other hand, sources for anaerobic digestion are available natural materials that are low costs, plentiful, and easy to exploit or utilize such as crops, sewage, municipal solid waste, animal residues, industrial residues, etc.

Common reed (Phragmites australis), a semi-aquatic grass, contributed around the world except for Antarctica continent. Found in swales, roadside ditches, stream, or pond [8] and widespread temperate and tropical climatic regions. As the other grasses, the characteristic of common reed with the stems, leaves, flowers and seed. Steam are erect, smooth, hollow and can grow up to six meters in height, leaves look like spear shape, and flowers contain brown seeds and arranged by hairs optimum range of temperature $30-35^{\circ} \mathrm{C}$, those parts contain lignocellulose component which is always enormous obstacle to decomposition, it comprises of cellulose, hemicellulose, and lignin. Biogas production from the grass in general and common reed, in particular, is containing great potential and there are limiting on research on this material.

There are many articles used various pre-treatment methods such as chemical mainly acids and bases [9] physical [4,10] and biological method. Each technique brings different effects besides the advantages that still exist limitations, but these are not significant. Moreover, combination methods are always remarkability by the ability to bring the impact ofeach method rather than using one way. Thus, this paper aimed to evaluate 
alkaline concentration for pre-treatment of common reed and investigate the ratio of substrates in fermentation with cow dung.

\subsection{Research Objective}

This study aims to evaluate optimal parameters for the substrate of common reed and cow dung with different ratios (i.e. 1:1, 2:1 and 1:2) for improving the quality of methane content and biogas production..

\section{MATERIALS AND METHODS}

\subsection{Preparation of substrates}

Common reed (Phragmites australis) was collected from a field in near Maejo University, Nong Han sub-district, San Sai district, Chiang Mai province, Thailand (at coordinate $\left.18^{\circ} 54^{\prime} 48.0^{\prime \prime} \mathrm{N}-98^{\circ} 59^{\prime} 30.2^{\prime \prime} \mathrm{E}\right)$.

Table 1. Substrates typical characterization

\begin{tabular}{|c|c|c|}
\hline \multirow{2}{*}{ Parameters } & \multicolumn{2}{|l|}{ Values } \\
\hline & Common reed & Cow dung \\
\hline $\begin{array}{l}\text { Total Solid (TS, } \\
\mathrm{mg} / \mathrm{L} \text { d.b)a }\end{array}$ & $488,000 \pm 2,483$ & $\begin{array}{ll}167,133 \quad \pm \\
9,051\end{array}$ \\
\hline $\begin{array}{l}\text { Volatile Solid (VS, } \\
\mathrm{mg} / \mathrm{L} \text { d.b) a }\end{array}$ & $462,000 \pm 1,414$ & $\begin{array}{ll}133,133 & \pm \\
4,759 & \end{array}$ \\
\hline $\mathrm{pH}$ & $5.69 \pm 0.02$ & $6.73 \pm 0.02$ \\
\hline COD (mg/L) & $85,333 \pm 13,597$ & $\begin{array}{ll}141,333 & \pm \\
30,868 & \end{array}$ \\
\hline VFA (mg/L) & $2,857.14 \pm 485.93$ & $\begin{array}{ll}4,130.90 \quad \pm \\
223.44\end{array}$ \\
\hline $\begin{array}{l}\text { Alkalinity } \\
\left.\mathrm{CaCO}_{3} / \mathrm{L}\right)\end{array}$ & $1,683.3 \pm 131.23$ & $\begin{array}{ll}2,983.33 & \pm \\
124.72 & \end{array}$ \\
\hline Ash Content (\%) & $7.00 \pm 0.43$ & $9.13 \pm 0.33$ \\
\hline Moisture (\%) & $51.20 \pm 0.25$ & $83.29 \pm 0.91$ \\
\hline Cellulose (\%) & $31.958 \pm 0.11$ & ND \\
\hline Hemicellulose (\%) & $29.034 \pm 0.06$ & ND \\
\hline
\end{tabular}

After collection, the common reed was shredded by chipping disk machine (multi-purpose shredder model MJU-EB8) and passed through sieve $5 \mathrm{~mm}$ to $20 \mathrm{~mm}$ to reduce and collect small particle size. After that, materials were transferred to the laboratory for pre-treatment method. Besides that, some parameters need to detect under dry basis; thus, grass has to airdried sample after one week then pulverized by a blender (Philip HR2116/01 600W).

Cow dung was gathered from cow's farm at Mae Faek Mai sub-district, San Sai district, Chiang Mai province, Thailand (at coordinate $18^{\circ} 58^{\prime} 52.6^{\prime \prime} \mathrm{N} 98^{\circ} 58^{\prime} 26.0^{\prime \prime} \mathrm{E}$ ), samples obtained in fresh condition to ensure nutrient-rich and maximize the microbial activity potential. Afterward, all sample was sealed by plastic bags and kept in dry storage until conduct fermentation, storage time should not exceed 12 hours.

\subsection{Alkaline pretreatment}

A plastic container with mouth width contained twist top cap was used for all pretreatments and the capacity of the container was 2 liters (L). Pre-treatment of common reed was set out using

https://doi.org/10.29165/ajarcde.v3i1.20 sodium hydroxide $(\mathrm{NaOH})$ with $2 \%$ concentration. The volume of $2 \% \mathrm{NaOH}$ solution used for material follows ratio $3: 1(\mathrm{v} / \mathrm{m})$. Based on the ratio of fermentation, that volume of $\mathrm{NaOH}$ used. The masses of grass were $125,187.5$, and 250 grams and $\mathrm{NaOH}$ have used 375, 563, and $750 \mathrm{ml}$, respectively. During 3 days of the pre-treatment feedstocks were mixed day by day and checked the changing of $\mathrm{pH}$. Especially, after second days, the samples were powdered by blender hereafter continue the pre-treatment process through 1 day remain Fig. 1 . Totally 15 containers were used for this batch. All samples from pre-treatment stored at room temperature $\left(22-25^{\circ} \mathrm{C}\right)$. Besides, the pretreated grass was airdried by solar dryer for a week and kept in plastic until use for analysis.

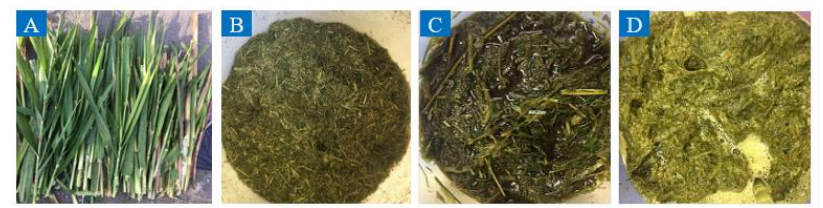

Fig. 1. Pretreatment of $2 \% \mathrm{NaOH}$ : (A) Raw material, (B) Particle size (C) Common reed after 3 days, and (D) After mixed by a blender.

\subsection{Anaerobic digestion (AD) of common reed}

The capacity of the fermenter was 3 liters, $15 \%$ total solid (TS) of substrates were computed [11]. as medium solids anaerobic digestion systems contain $15 \%$ - 20\%. Thus, 375 grams were estimation for fermentation to match with 2.5 liters working volume. The solid states were a combination of cow dung and common reed in anaerobic co-digestion. Moreover, to investigate the productivity of substrates 3 ratios accompanied as 3 treatments (T): T1 (1:2), T2 (1:1), and T3 (2:1) each ratio with 3 replications. In other words, the ratio of common reed: cow dung was followed (by mass) as 125:250, 187.5:187.5, and 250:125 (grams). To reach 2.5 liters level 2 liters of distilled deionized water was added. Besides, control tests of both common reed and cow dung were implemented to compare the effectiveness of the system.

All experimental setups were run in triplicate, the fermenters were recapped by rubber stoppers, and gas outlet will go through equipped pipes with the valve to collect samples. Moreover, the bioreactors undergo ambient temperature during summertime with the range $26^{\circ} \mathrm{C}-40^{\circ} \mathrm{C}$ and shake by manual 3 times per day to ensure that the bacterial communities survival and decompose organic matter via the nutrient from the substrate in fermenters. The capacity of gasholders was 1 liter. Before fermentation happened all air (oxygen and other trace gases) would be taken out from pipes, gas holders, and fermenters by rubber aspirator to insure anaerobic condition Fig 2. The gas produced was measured equivalent to the volume of water decreased from gasholders. Those experiments were run until generating of methane from system discontinue. 


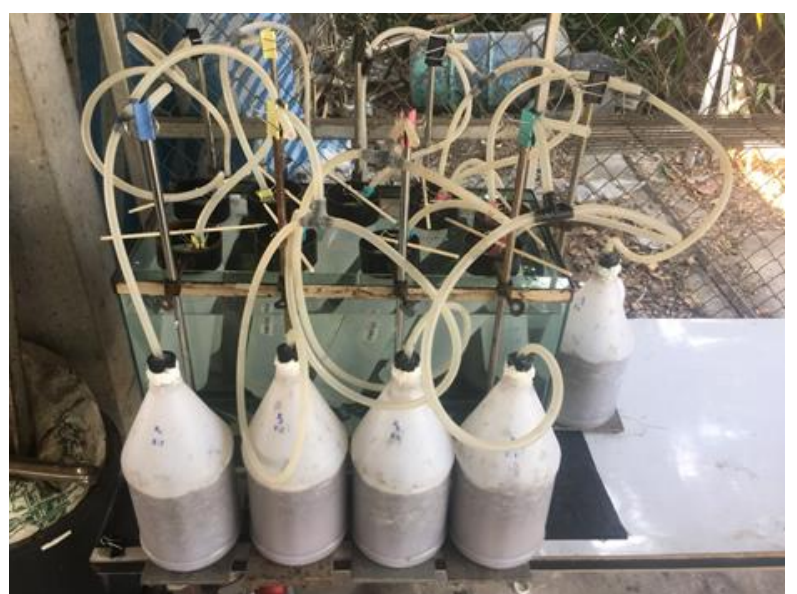

Fig. 2. Experiment set up

\subsection{Analytical methods}

All parameters in this study were conducted in triplicates and followed: TS (total solid), VS (volatile solids), moisture, volatile fatty acids (VFA), alkalinity (ALK), and chemical oxygen demand (COD) were detected according to the standard methods for the examination of water and wastewater [16]. Ash content was measured according to AOAC official method 942.05 [17]. The $\mathrm{pH}$ value was tested by $\mathrm{pH}$ meter (Oakton PCSTestr 35 waterproof). Carbon and nitrogen contents of the material were determined by C-H-N-S-O analyzer (2400 II CHNS/O Elemental Analyzer, Perkin-Elmer, USA). The cellulose, hemicellulose, and lignin contents were determined and estimated base on a dry basis. The method was adopted by $\mathrm{Vu}$ et al. [18].

\subsection{Estimation of gas production and energy analysis}

The volume of biogas was monitored and recorded every day; the cumulative gas measured base on the results that noted from daily gas generated. Every 3 days produced gas was collected in the gas sampling bag with $1 \mathrm{~L}$ working volume (Tedlar PVF PTFE valve, China) and was stored in dry storage and the continuous temperature range from $-70^{\circ} \mathrm{C}$ to $100^{\circ} \mathrm{C}$. The volume of gas used for checking components was $400 \mathrm{ml}-1000 \mathrm{ml}$.

Biogas composition such as $\mathrm{CH}_{4}, \mathrm{CO}_{2}, \mathrm{O}_{2}$, and $\mathrm{H}_{2} \mathrm{~S}$ was analyzed by gas analyzer (Biogas 5000 - Geotech, England) an equipment with size (L) $220 \mathrm{~mm} \times$ (W) $155 \mathrm{~mm} \times$ (D) $60 \mathrm{~mm}$ provides 2 main port, 1 for outlet after checking gas the other to measure gas compositions which were displayed on the small LCD screen. Equipped flow of pump $550 \mathrm{ml} / \mathrm{min}$, temperature for measurement from $-10^{\circ} \mathrm{C}$ to $75^{\circ} \mathrm{C}$. Calorific values were estimated according to Ref. [12].

\section{RESULT AND DISCUSSION}

\subsection{TS and VS reduction}

Biogas is produced from the biological conversion of substrates which is represented by the amount of dry matter of substrate, also known as TS and VS [13]. TS and VS of raw materials were calculated and the results were shown in Tables 1 . The utilization of TS and VS were presented the efficiency of anaerobic decomposition, the amount of biomass was used by microorganisms through which the microbial community proliferate to produce more gas. In other words, by checking the 30 Giang Van Tran et al. concentration before and after the fermentation, the consumption of these parameters will be assessed directly. In this study, the range of degradation efficiency of treatments was $62.03 \%$ $74.45 \%$. Meanwhile, the range of control test was $38.80 \%-$ $43.21 \%$ (Fig. 3). The results proved that the co-digestion of material always give more potential for producing due to the abundance of nutrients in the substrate helps microorganisms thrive more smoothly. Moreover, available components in feedstock after $\mathrm{NaOH}$ pretreatment more chance to present the significant improvement on biodegradability [14, 15]. Hence, could explain the reason why biogas production of $\mathrm{NaOH}$-treated common reed was greatly increased.
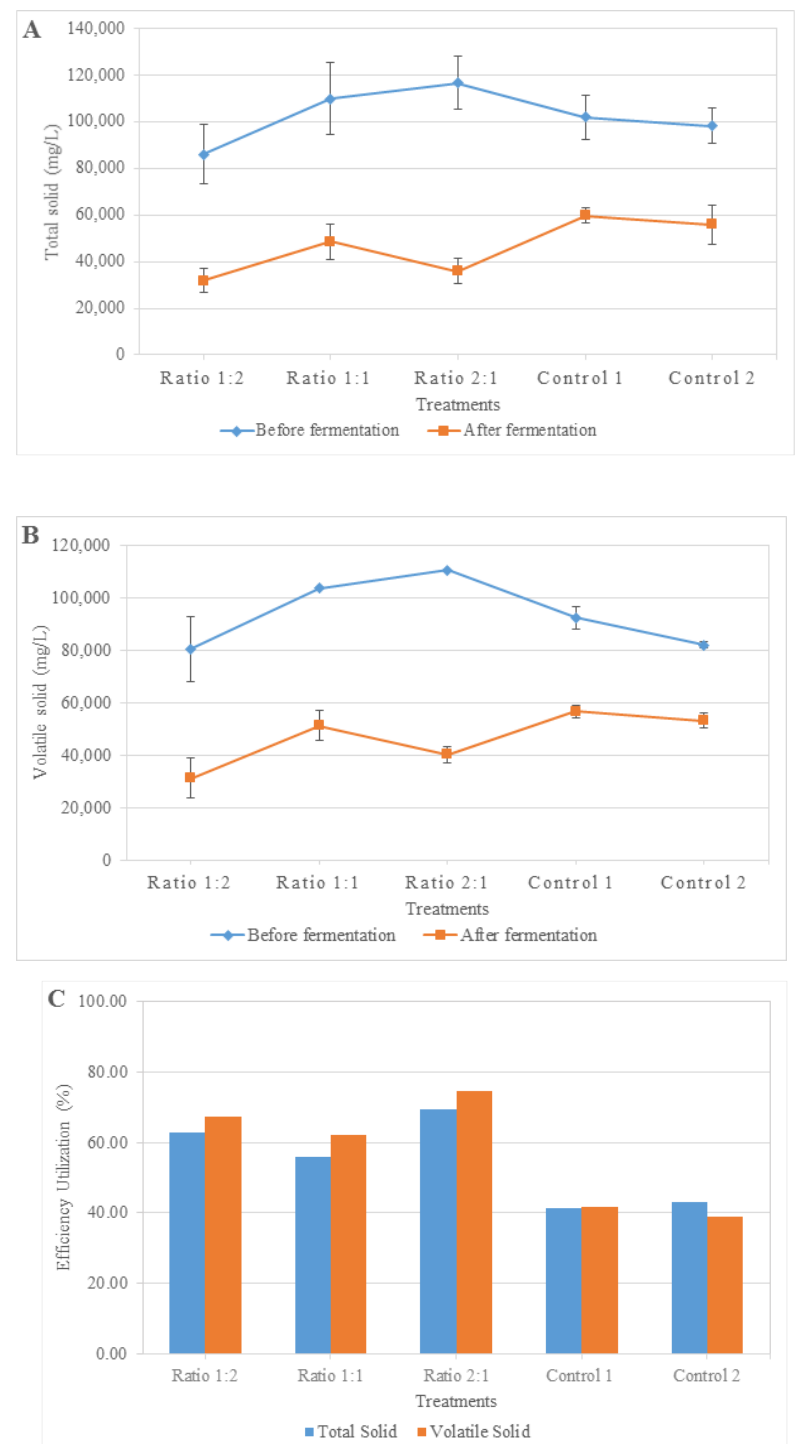

Fig. 3. TS and VS reduction: (A) Total solid, (B) Volatile solid, and $(\mathrm{C})$ Degradation efficiency

In fact, in addition to TS and VS, there is another parameter that is COD, which has influence is relatively large as the above two parameters. It is often known for its ability to remove COD during the fermentation process. The COD removal was obtained at range $36.4 \%-52.38 \%$.

\subsection{Variation of $\mathrm{pH}, \mathrm{VFA}$, and alkalinity}

Due to the sensitivity of microorganism in the fermentation process. Therefore, the $\mathrm{pH}$ is an extremely important parameter

https://doi.org/10.29165/ajarcde.v3i1.20 
for operation an experiment system and observing the anaerobic digestion process. Affection might depend on VFA and buffering capacity. Acidogenesis stage where produces acidogenic bacteria which makes $\mathrm{pH}$ value decrease caused accumulation of VFA [20]. The initial $\mathrm{pH}$ value in this study was kept at 7 , suitable for the essential range for anaerobic bacteria $6.5-8$. Certainty, in the first few days of HRT the $\mathrm{pH}$ value would be decreased by formation some acid such as mainly acetic acid, propionic acid, and butyric acid and small amounts of other acids. However, alkalinity curbs the possibility of falling into an acidic environment. Subsequently, $\mathrm{pH}$ values increased around 7 or even higher until accomplishing the fermentative process.

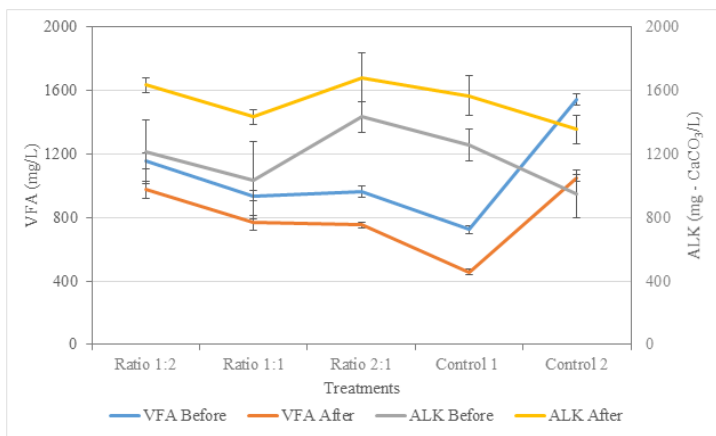

Fig. 4. The Alkalinity and VFA od Substrates

The alkalinity and VFA of substrates were shown in Fig. 4 and in anaerobic systems should be in the range of $500-2,000$ $\mathrm{mg} / \mathrm{L}$ and $1,000-5,000 \mathrm{mg} / \mathrm{L}$ and should have VFA/alkalinity ratio less than 0.4 . In this work, the range was $700-1500 \mathrm{mg} / \mathrm{L}$ and $1300-1700 \mathrm{mg} / \mathrm{L}$, respectively. The increase of alkalinity due to the consumption of VFA by methanogens what happens in most experiments, and also shows that the influence of VFA on the process is higher than that of ALK. Hence, VFAs plays an important role in sustaining efficient anaerobic digestion as well as affects the $\mathrm{pH}$ value, alkalinity, and the activity of methanogens [20].

\subsection{Biogas production of co-digestion}

The cumulative gas production was shown in Fig. 5 for the $\mathrm{NaOH}$ pretreatment with two control test and three varying concentrations of $1: 2,1: 1$, and 2:1.

The pretreatment of material not only contributes to the accelerating of biogas production but also increasing the methane content significantly, as evidenced by the peaks which have shown in the graph. The results were pointed out that within 45 days of fermentation ratio 2:1 presented the highest yield and methane contents are $20,015 \mathrm{ml}$ and $70.3 \%$, respectively. Whereas, ratio $1: 2$ reached $65.8 \%$ with $11,870 \mathrm{ml}$ volume gas and lower was $1: 1$ have got $62.2 \%$ of methane, total gas was 14,900 $\mathrm{ml}$. In other words, the yields of ratios were $362.26 \mathrm{ml} \mathrm{CH} 4 / \mathrm{g}$ VS, $287.92 \mathrm{ml} \mathrm{CH}_{4} / \mathrm{g} \mathrm{VS}$, and $295.03 \mathrm{ml} \mathrm{CH} 4 / \mathrm{g} \mathrm{VS}$. In case of pretreated $\mathrm{NaOH}$ without co-digestion as control of substrate for the biogas production which was run on two separate material as common reed present for control 1 and cow dung present for control 2. These controls were completely undergone 45 days of HRT and obtained that total gas was $6,290 \mathrm{ml}$ and $10,157 \mathrm{ml}$ with highest methane contents were $40.20 \%$ and $60.1 \%$, respectively. Hence, to assess the potential as well as the production efficiency of co-digestion of fermentation.

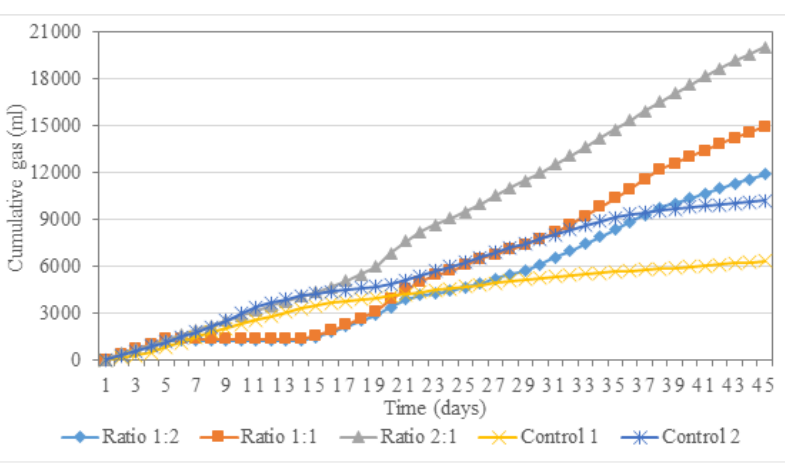

Fig. 5. Cumulative of biogas production

The content of methane, carbon dioxide, oxygen, and hydrogen sulfide production yields produced from untreated and pretreated common reed and cow dung substrates was revealed in Fig 6. Control 1 and control 2 have resulted lower than. Biogas production was completely stopped after 45 days of HRT. Oxygen and sulfide gas tend to decrease during fermentation. Meanwhile, Methane has a significant increase besides carbon content also generated by the anaerobic process.

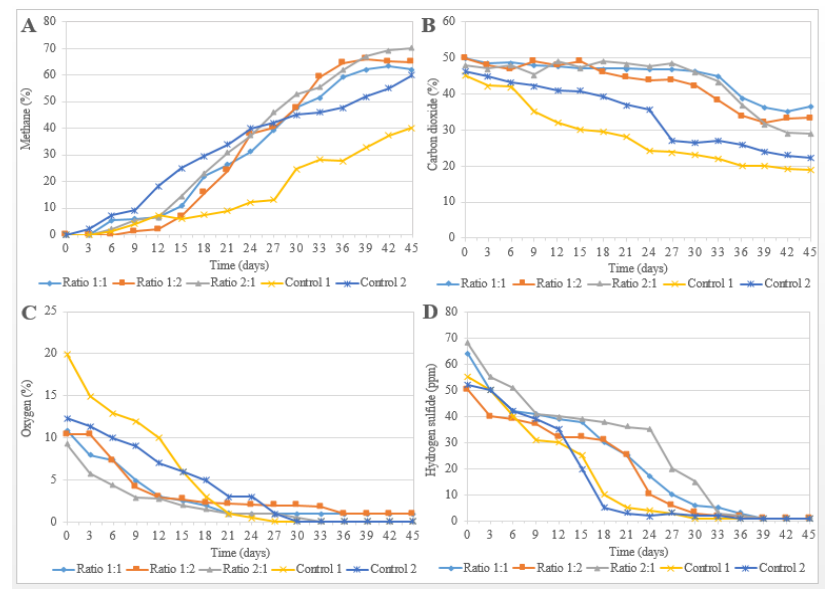

Fig. 6. Variation of gas composition: (A) Methane $\left(\mathrm{CH}_{4}\right)$, (B), Carbon dioxide $\left(\mathrm{CO}_{2}\right)$, (C) Oxygen $\left(\mathrm{O}_{2}\right)$, and (D) Hydrogen Sulfide $\left(\mathrm{H}_{2} \mathrm{~S}\right)$.

The results were observed more than $90.0 \%$ of biogas and methane yield produced rapid up to at 30 days of HRT and during next 15 days of HRT only about $5.0 \%$ of biogas and $5.0 \%$ is a decline of another gas trace, as well as methane, were produced. The changes of components of biogas were expressed in Fig 6 . The composition of the gas changes every day but on the 15 th day of HRT onwards, the change is really significant which proves that the microorganisms are active at this time and easily adaptable. Hence, increase the bacterial community. Besides, some unnecessary gas components will be reduced and gradually transformed to produce more necessary gas products. The actual calorific value of the biogas is a function of the $\mathrm{CH}_{4}$ percentage, the temperature and the absolute pressure, all of which differ from case to case. The calorific value of the biogas is a crucial parameter for the performance of an engine, a burner or any other application using biogas as a fuel. Consequently, study results were suggested that at ratio 2:1 (common reed and cow dung) 
contain heating value of the biogas was $39.40 \mathrm{MJ} / \mathrm{m} 3$. High heating value (HHV) was $27.80 \mathrm{MJ} / \mathrm{m}^{3}$ and low heating value (LHV) was $25.04 \mathrm{MJ} / \mathrm{m} 3$.Furthermore this experimental results proposed that methane enhancement and further scale up studies could be applicable.

\section{CONCLUSION}

The pretreatment of solid-state with alkali pretreatment for 3 days and concentrations substrate could effect on the common reed with a significant change of lignocellulose content and metabolism. The substrates of anaerobic digestion with $2 \%$ $\mathrm{NaOH}$-pretreated common reed produced $49 \%$ more biogas when compared to the untreated with $70.1 \%$ methane and yield of cosubstrate $362.26 \mathrm{ml} \mathrm{CH}_{4} / \mathrm{g}$ VS. The changes of chemical structures were contributed to the improvement of biodegradability, accessibility of microorganism and the enrichment of biogas production.

\section{ACKNOWLEDGMENT}

Authors gratefully acknowledged for the School of Renewable Energy and were carried out using equipment from Faculty of Science, Maejo University, Chiang Mai, Thailand.

\section{REFERENCE}

[1] Appels, L., Lauwers, J., Degrve, J., Helsen, L., Lievens, B., Willems, K., Dewil, R. (2011). Anaerobic digestion in global bio-energy production: Potential and research challenges. Renewable and Sustainable Energy Reviews, 15(9), 4295-4301.

[2] Ramaraj, R., Unpaprom, Y. \& Dussadee N. (2016). Cultivation of green microalga, chlorella vulgaris for biogas purification. International Journal of New Technology and Research, 2, 117-122.

[3] El-Shinnawi, M. M., El-Din, M. N. A., El-Shimi, S. A., \& Badawi, M. A. (1989). Biogas production from crop residues and aquatic weeds. Resources, Conservation and Recycling, 3(1), 33-45.

[4] Kaewdiew, J., Ramaraj, R., Koonaphapdeelert, S., Dussadee, N. (2019). Assessment of the biogas potential from agricultural waste in northern Thailand. Maejo International Journal of Energy and Environmental Communication, 1(1), 40-47.

[5] Van Tran, G., Unpaprom, Y. \& Ramaraj, R. (2019). Methane productivity evaluation of an invasive wetland plant, common reed. Biomass Conversion and Biorefinery. https://doi.org/10.1007/s13399-019-00451z.

[6] Alexandropoulou, M., Antonopoulou, G., Fragkou, E., Ntaikou, I., \& Lyberatos, G. (2017). Fungal pretreatment of willow sawdust and its combination with alkaline treatment for enhancing biogas production. Journal of Environmental Management, 203, 704-713.

[7] Dehghani, M., Karimi, K., \& Sadeghi, M. (2015). Pretreatment of rice straw for the improvement of biogas production. Energy and Fuels, 29(6), 3770-3775.

[8] Lizasoain, J., Rincón, M., Theuretzbacher, F., Enguídanos, R., Nielsen, P. J., Potthast, A., Bauer, A. (2016). Biogas production from reed biomass: effect of pretreatment using different steam explosion conditions. Biomass and Bioenergy, 95, 84-91.

[9] Hendriks, A. T. W. M., \& Zeeman, G. (2009). Pretreatments to enhance the digestibility of lignocellulosic biomass. Bioresource Technology, 100 (1), 10-18.

[10] Agyeman, F. O., \& Tao, W. (2014). Anaerobic codigestion of food waste and dairy manure: Effects of food waste particle size and organic loading rate. Journal of Environmental Management, 133, 268-274

[11] Nalo, T., Tasing, K., Kumar, S., \& Bharti, A. (2014). Anaerobic digestion of municipal solid waste: a critical analysis. International Journal of Innovative Research in Science, 3(4), 224-234.

[12] Li, Y., Liu, H., Yan, F., Su, D., Wang, Y. \& Zhou, H. (2017) High-calorific biogas production from anaerobic digestion of food waste using a two-phase pressurized biofilm (TPPB) system. Bioresource Technology, 224, 56-62.

[13] Zheng, M., Li, X., Li, L., Yang, X., \& He, Y. (2009). Enhancing anaerobic biogasification of corn stover through wet state $\mathrm{NaOH}$ pretreatment. Bioresource Technology, 100(21), 5140-5145.

[14] Chuanchai, A., \& Ramaraj, R. (2018). Sustainability assessment of biogas production from buffalo grass and dung: biogas purification and bio-fertilizer. 3 Biotech, 8 , 151.

[15] Wannapokin, A., Ramaraj, R., Whangchai, K., \& Unpaprom, Y. (2018). Potential improvement of biogas production from fallen teak leaves with co-digestion of microalgae. 3 Biotech, 8, 123.

[16] APHA (2005). Standard methods for the examination of water and wastewater, 21st edition. American Public Health Association, Washington, DC.

[17] AOAC (2012). Official Methods of Analysis of AOAC international. 19th edition. AOAC International, Gaithersburg, Maryland, USA

[18] Vu, P. T., Unpaprom, Y., \& Ramaraj, R. (2018). Impact and significance of alkaline-oxidant pretreatment on the enzymatic digestibility of Sphenoclea zeylanica for bioethanol production. Bioresource Technology, 247, 125-130.

[19] Zhu, J., Wan, C., \& Li, Y. (2010). Enhanced solid-state anaerobic digestion of corn stover by alkaline pretreatment. Bioresource Technology, 101(19), 75237528.

[20] Møller, H. B., Sommer, S. G., \& Ahring, B. K. (2004). Biological degradation and greenhouse gas emissions during pre-storage of liquid animal manure. Journal of Environmental Quality, 33(1), 27-36. 